\title{
Improving the Learning Process in Producing Bio- charcoal Briquettes from Durian Peels/Banana Midrib with Various Particle Sizes and Composition to High School Students
}

\author{
Asep Bayu Dani Nandiyanto*, Alma Tyara Simbara, Ahmad Mudzakir, Rina Maryanti \\ Departemen Pendidikan Kimia, Universitas Pendidikan Indonesia, J1. Dr. Setiabudhi No. 229 Bandung, Indonesia \\ nandiyanto@upi.edu, almatyrs14@upi.edu, mudzakir.kimia@upi.edu, maryanti.rina@upi.edu
}

\begin{abstract}
This study aims to determine the best carbon particle size and composite variant and to teach students about the making of bio-charcoal briquettes from a mixture of durian peels with banana midribs. This research uses the carbonization methods at a temperature of $200-350^{\circ} \mathrm{C}$ for $4-$ $8 \mathrm{~h}$ to make briquettes with variations in carbon particle sizes of 104 and $250 \mu \mathrm{m}$, and in the composition of durian peels and banana midribs of 50:50, 60:40, and 70:30 using adhesive tapioca flour and water in a ratio of $1: 2$. This study also analyzes the level of students' understanding through a short survey using 12 pretest-posttest questions supported by learning media using video, where the research subjects are 30 high school students in Indonesia. The results show that the best briquettes obtained from printing using a $19.6 \mathrm{~kg}$ compaction load are cylindrical briquettes with a carbon particle size of $250 \mu \mathrm{m}$ and a composition variation of 70:30. In addition, the results of teaching students show that most students experienced an increase in understanding of briquettes after being given learning through video. This research is important in informing how to use biomass waste into briquettes to solve the current energy shortage problem.
\end{abstract}

Keywords: Banana midribs, Briquettes, Durian peels, Students, Teaching, Video,

\section{Corresponding Author}

*Departemen Pendidikan Kimia, Universitas

Pendidikan Indonesia, Jl. Dr. Setiabudi No. 229

Bandung, Indonesia

*nandiyanto@upi.edu

\section{Introduction}

Bio-charcoal briquettes are solid fuels with low volatile matter (Indah and Dahlan, 2012). The main raw material for making bio-charcoal briquettes consists of organic waste with the main content of cellulose, such as biomass waste
(Hendra, 2011). Briquettes have benefits as one of the alternative energies for replacing the use of fuel oil (Yaumal and Irsad, 2018). Indonesia has potential raw materials for the briquette-making process. This potential can be used to convert biomass into alternative energy with a capacity of 50,000 MW (Nuriana, Anisa, and Martana, 2014).

One of the prospective raw materials for briquettes is durian and banana. Durian is an exotic fruit originating from tropical regions (Feng, Wang, Yi, Yang, and He, 2004). The fruit pulp with the nickname the king of fruit has a weight percentage of $20-35 \%$ and is very popular in Indonesia with the harvest season occurring throughout the year (Zulkarnair, 2017). This means, the weight percentage of durian skin can reach $60-75 \%$ and is disposed of, becoming garbage and polluting the environment (Rahman, 2018). Banana plants in Indonesia can reach 800,000 trees each year. $80 \%$ of these plants are processed into various products and the banana midribs waste produce approximately 640,000 (Masthura, 2019). Needless to say, when compared with other raw materials in Indonesia, the durian peels and banana midribs have a high potential for conversion into biobriquettes.

The practice of converting biomass into alternative energy in Indonesia needs to be started. And, it must be started from the understanding of this knowledge to students (as the future generation) regarding the manufacture of fuels that are simple such as briquettes. This understanding can be obtained by students from the learning process. The learning process requires methods and media that accommodate students' needs. Thus, students can understand the material being taught comprehensively. Teachers can use one of the methods, namely experimental demonstration (Maryanti, Hufad, Sunardi, Nandiyanto, and Al-Obaidi, 2020). This method prioritizes the provision of material using demonstrations that make students observe directly and engage in learning (Rohendi, Sutarno, and Ginanjar, 2010). Demonstrations are conducted by showing the sequence of activity, either directly or using teaching media relevant to 
the subject presented (Nurul and Diyah, 2018). Efendi and Suswanto (2014) conducted demonstrations and experiments on vocational students, indicating that the experimental demonstration methods can increase student activities and learning outcomes. Nandiyanto, Raziqi, Dallyono, and Sumardi (2020) combined conventional learning and experimental demonstration for high school students, showing that the use of media can improve and stimulate students' curiosity and interest in the materials provided. Asmara (2015) developed audio-visual based instructional media for senior high school students on making colloids. The average score obtained from the test results is very good, so it can be concluded that learning using audio-visual media is more effective than learning without media. Hidayati, Adi, and Praherdhiono (2019) conducted a study on the development of instructional videos, stating that the use of video in learning can enhance students' understanding. However, up to the present, researches on learning using experimental demonstration methods and video media on making briquettes from a mixture of durian peels and banana midribs for high school students are still limited, while learning on briquette production is essential for students.

Therefore, this study aims to determine the size of carbon particles and the best composition of the durian peels with banana midribs mixture and teach high school students how to produce it themselves through video learning media. The making of briquettes is carried out by the carbonization methods which will produce carbon (charcoal) (Nuriana, Anisa, and Martana, 2014). Researches on the production of briquettes from durian peels or banana midribs usually use a size of $149-177 \mu \mathrm{m}$. The present study tries to use sizes of 104 and $250 \mu \mathrm{m}$. If the particle size is too small (less than $104 \mu \mathrm{m}$ ), the percentage of durability index value will be small and the briquettes become brittle, whereas if the particle size is too large (more than $250 \mu \mathrm{m}$ ) the combustion process will be inefficient.

We use a comparison of the composition of raw materials with a greater percentage of durian peel. This is conducted because the texture composition of the durian peels is better than banana midribs which tend to be hollow. Thus, if the percentage of banana midribs is greater, the quality of the resulting briquettes will decrease (Masthura, 2019). To determine the quality of the briquettes produced, the study is equipped with characterizations: compressed density (CD) testing, relaxed density (RD), relaxation ratio (RR), percentage moisture content (PMC), percentage of water resistance index (PWRI), water boiling test (WBT), burning rate (BR), specific fuel consumption (SFC), and percentage of durability index (PDI). This study is also accompanied by an analysis of the students' understanding of briquettes level which is assessed through a short survey using 12 pretestposttest questions.

The systematic stages are carried out starting from assessing students' abilities (pretest), delivering teaching on briquette making supported by theoretical explanations through video learning media, and reassessing student abilities (posttest). The analysis is supported by direct evaluation (through assessment). The discovery of quality briquettes and the improvement of students' understanding of the manufacture of briquettes from durian peels and banana midribs are the expected results of this study. This research is useful for informing the results of making briquettes from durian peels and banana midribs that have never been studied by other researchers.

\section{Theoretical Framework}

Briquettes are solid fuels that can be produced from biomass conversion (Irhamni, Saudah, Hakim, Diana, Suzanni, and Ernilasari, 2019). Bio-charcoal briquettes can be produced from high-temperature heating technology of materials containing carbon, resulting in alternative fuels in the form of porous solids with the ability to produce heat up to 5,000 calories (Sudradjat, Setiawan, and Roliadi, 2006).

Figure 1 shows an illustration of the process of converting biomass into synthetic fuel. Students' understanding of briquette making will be easily formed through experimental demonstration. They can understand the concept with the help of (visual) illustrations (Hidayati, Adi, and Praherdhiono, 2019).

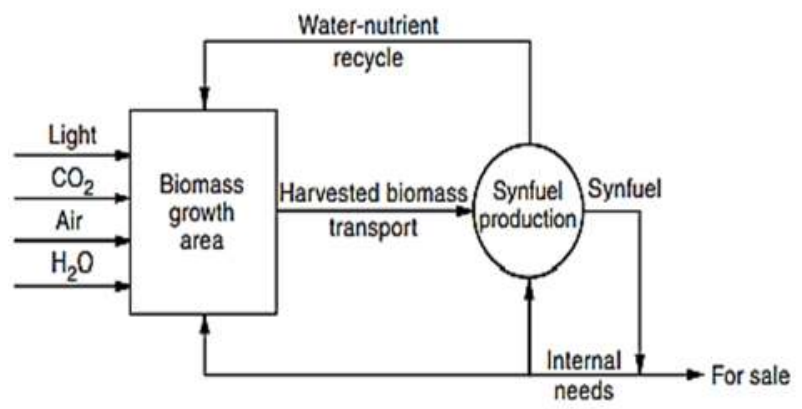

Fig. 1 Diagram of the process of converting biomass to synthetic fuel (Christian, 2000).

Figure 2 is an illustration of the process of making briquettes from biomass waste. One of the standardization quality and characteristics for good briquettes (SNI 01-6235 (2000)) is to have a calorific value of at least $5000 \mathrm{cal} / \mathrm{gram}$ (Irhamni, Saudah, Hakim, Diana, Suzanni, and Ernilasari, 2019). The calorific value of a fuel is obtained using a bomb calorimeter. The principle includes calculating the heat absorbed by water in the bomb calorimeter. This principle can be described through equations (Elfiano, Subekti, and Sadil, 2014).

$\mathrm{Q}=\mathrm{m} \cdot \mathrm{C}_{\mathrm{p}} \cdot \Delta \mathrm{T}$

where $\mathrm{Q}$ is the heat absorbed, $\mathrm{m}$ is the mass of water in a bomb calorimeter $(\mathrm{g}), \mathrm{C}_{\mathrm{p}}$ is the specific heat $4.186 \mathrm{~kJ} / \mathrm{kg}^{\circ} \mathrm{C}$. 


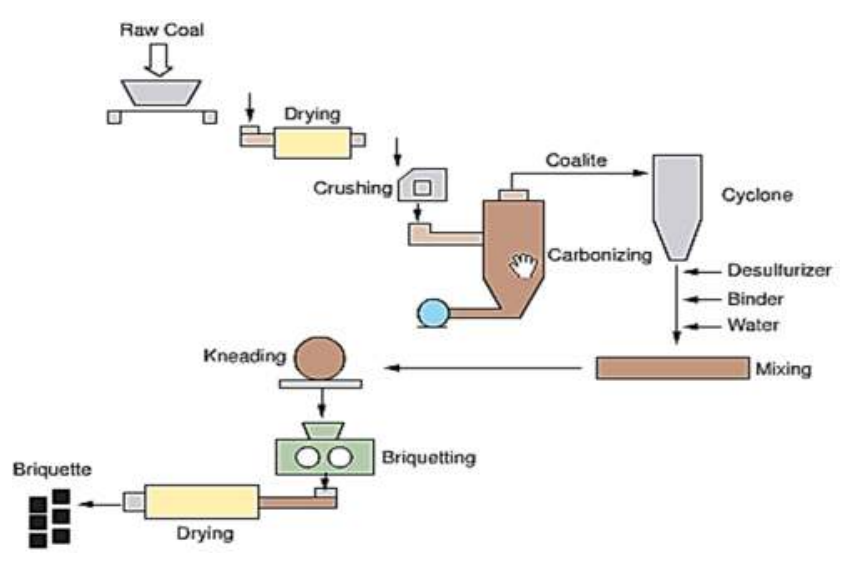

Fig. 2 Diagram of the briquette manufacturing process (Gemco, 2020). The explanation of briquette making and characterization is difficult to teach to students who are slow in learning as they take a longer time to understand (Maryanti, Hufad, Sunardi, Nandiyanto, and Al-Obaidi, 2020). Table 1 shows a comparison of previous research with this study. This state-of-the-art research is taken from several examples of previous research as a guide or examples for current research. Examples taken are journals on the manufacture of briquettes from durian peels and banana midribs.

Table 1. State of The Art

\begin{tabular}{|c|c|c|c|c|c|}
\hline No. & Researcher & Title & Methods & Result & Differences with this study \\
\hline 1. & $\begin{array}{l}\text { Nuriana, Anisa, } \\
\text { and Martana } \\
(2013)\end{array}$ & $\begin{array}{l}\text { Characteristics of Durian Skin } \\
\text { Biobriquettes as Renewable } \\
\text { Alternative Fuels }\end{array}$ & Carbonization & $\begin{array}{l}\text { Durian skin briquettes are } \\
\text { cylindrical with a diameter of } 3.8 \\
\mathrm{~cm} \text {, a height of } 6.5 \mathrm{~cm} \text {, and a size } \\
\text { of } 149 \mu \mathrm{m} \text {. }\end{array}$ & $\begin{array}{l}\text { Using the different-test } \\
\text { parameter. }\end{array}$ \\
\hline 2. & $\begin{array}{l}\text { Nuriana, Anisa, } \\
\text { and Martana } \\
\text { (2014) }\end{array}$ & $\begin{array}{l}\text { Synthesis Preliminary Studies } \\
\text { Durian Peels Biobriquettes as } \\
\text { an Alternative Fuels }\end{array}$ & Pyrolysis & $\begin{array}{l}\text { Briquettes with } 77.87 \% \text { carbon } \\
\text { content, } 0.01 \% \text { moisture, content, } \\
0.09 \% \text { moisture content, } 0.99 \\
\mathrm{~g} / \mathrm{mL} \text { density, and a calorific value } \\
\text { of } 6274.29 \mathrm{kcal} / \mathrm{kg} \text {. }\end{array}$ & $\begin{array}{l}\text { The method used is } \\
\text { carbonization. The raw } \\
\text { materials used are durian peels } \\
\text { and banana midribs. }\end{array}$ \\
\hline 3. & $\begin{array}{l}\text { Kemas Ridhuan } \\
\quad \text { and Joko } \\
\text { Suranto (2016) }\end{array}$ & $\begin{array}{l}\text { Comparison of Combustion of } \\
\text { Pyrolysis and Carbonization in } \\
\text { Durian Skin Biomass Against } \\
\text { Calorific Value }\end{array}$ & $\begin{array}{l}\text { Pyrolysis and } \\
\text { Carbonization }\end{array}$ & $\begin{array}{l}\text { The briquettes from the pyrolysis } \\
\text { process produce a higher heating } \\
\text { value than the carbonization } \\
\text { process. }\end{array}$ & $\begin{array}{l}\text { Do not do a method } \\
\text { comparison, but do a } \\
\text { comparison of the composition } \\
\text { of raw materials (durian peels } \\
\text { and banana midrib). }\end{array}$ \\
\hline 4. & Kalsum (2016) & $\begin{array}{l}\text { Making Charcoal Briquettes } \\
\text { from a Mix of Corn Cobs, } \\
\text { Durian Bark, and Sawdust } \\
\text { Using Tapioca Adhesives }\end{array}$ & Carbonization & $\begin{array}{l}\text { Briquettes made from a mixture of } \\
50 \% \text { wood sawdust, } 10 \% \text { corn } \\
\text { cobs, } 40 \% \text { durian skin produced } \\
\text { the highest calorific value at } \\
\text { carbonization of } 500^{\circ} \mathrm{C} \text {. }\end{array}$ & $\begin{array}{l}\text { The raw materials used are } \\
\text { durian peels and banana } \\
\text { midribs. The carbonization } \\
\text { temperature used is } 250-350^{\circ} \mathrm{C}\end{array}$ \\
\hline 5. & Masthura (2019) & $\begin{array}{l}\text { Physical Analysis and Burning } \\
\text { Rate of Bio-charcoal Briquettes } \\
\text { from Banana Stems }\end{array}$ & Experimental & $\begin{array}{l}\text { The best composition between } \\
\text { banana and tapioca flour is } 60 \text { : } \\
40 \% \text {. }\end{array}$ & $\begin{array}{l}\text { The method used is } \\
\text { carbonization. The raw } \\
\text { materials used are durian peels } \\
\text { and banana midribs }\end{array}$ \\
\hline
\end{tabular}

\section{Methods}

\subsection{Making Bio-Charcoal Briquettes}

A briquette mixture of durian peels and banana midribs is made by collecting waste durian peels and banana midribs in Tasikmalaya, Indonesia. Durian peels and banana midribs are cut into small pieces and dried naturally for about 3 days. Both raw materials are then carbonized for 4-8 $\mathrm{h}$. The carbon residue is crushed and sieved (using a 60 and 150 mesh sieve) to obtain carbon particles with sizes of 250 and 104 $\mu \mathrm{m}$. The commercial tapioca flour (Rose brand from PT Budi Acid Jaya Tbk) and water (1:2 ratio) are used as binders, which are then mixed and compacted the carbon from durian peels and banana midribs.

Figure 3 shows the stages of making and characterizing briquettes from a mixture of durian peels and banana midribs. The composition of the two raw materials is modified into three ratios of durian peels: banana midrib, namely 50:50, 60:40, and 70:30. The briquettes are molded using a compaction load of $19.6 \mathrm{~kg}$ at a diameter of $3 \mathrm{~cm}$ and a thickness of $1 \mathrm{~cm}$.
Characterization test data obtained by threefold repetition. The data are analyzed and plotted into $\mathrm{CD}, \mathrm{RD}$, RR, PMC, PWRI, WBT, BR, SFC, and PDI graphs for variants in the composition of raw materials at carbon particle sizes of 250 and $150 \mu \mathrm{m}$. Besides, characterization data is also analyzed or validated using Anova Two Ways Factor

\subsection{Teaching methods}

The subjects are 30 students (secondary school and vocational school) in Tasikmalaya city, Indonesia. The trial is conducted in three stages, each of which is evaluated using the direct observation methods (through assessment).

- In the first stage, students are given pretest questions to find out the student's knowledge about briquettes that may have been obtained.

- In the second stage, students are given teaching materials on making bio-charcoal briquettes from a 
mixture of durian peels and banana midribs through video learning media. In the video, a theoretical explanation about the definition of biomass, briquettes, and the effect of the variant in composite, carbon particle size, compaction load, and the addition of adhesive in briquette making-process is added. A diagram of the characterization results is also provided with the aim of students being able to analyze and understand the influence of research variables in making this bio-charcoal briquette.

- In the third stage, students are given post-test questions so it could be seen whether there is an increase in understanding after being given a learning video.

- The number of pretest-posttest questions given to students is 12 questions and all questions are relevant to the learning video given. The questions are True-False questions.

- Students' ability to analyze is conducted using a score scale of 0 and; where 0 means False and 1 means True. The total score of each answered question is converted into units of $\%$.

- The pretest-posttest score data are analyzed using nonparametric statistical tests (Wilcoxon signed-rank test analysis).

The students' demography data, including basic students' information including IQ scores and the average score of Mathematics, Chemistry, Physics, and Biology, are obtained before starting the three stages to support the research instrument. The IQ score technique is conducted through an IQ test on the official website (tes-iq.com), while the scoring technique of Mathematics, Chemistry, Physics, and Biology is carried out by adding and dividing the scores (average) of each student.

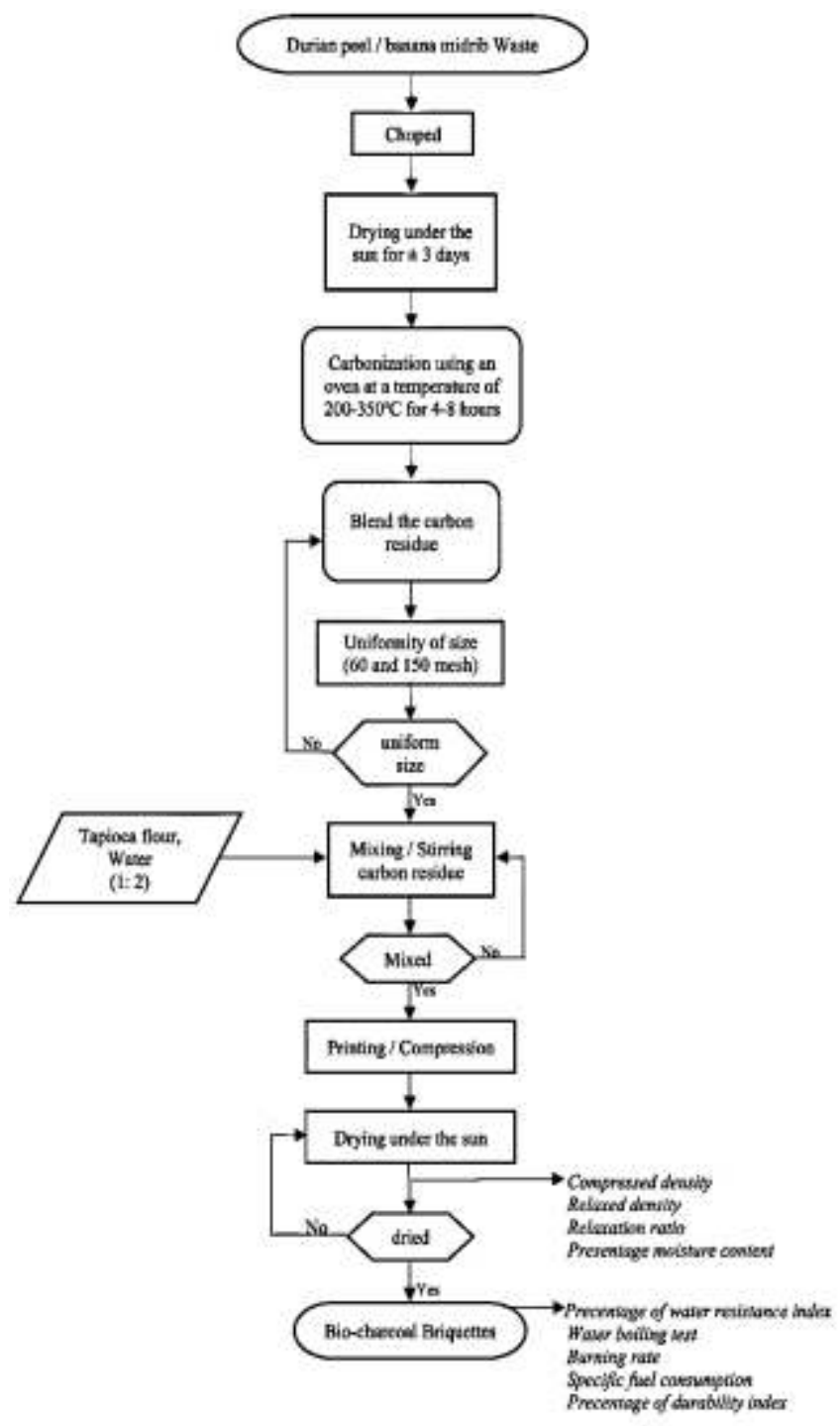

Fig. 3 Flow charts of the production and characterization bio-charcoal briquettes, a mixture of durian peels waste and banana midribs.

\section{Results and Discussions}

The results and discussion section includes an explanation of the characterization of briquettes according to the parameters used, data analysis/Validation with ANOVA, and the qualitative analysis of students' teaching test results.

\subsection{Briquette characterization and Data Analysis}

Briquette characterization is carried out using nine parameters. Data analysis/Validation is performed using the two-way ANOVA method. Carbon particle size becomes the first independent variable with the 104 and $250 \mu \mathrm{m}$ categories. Variations in the composition of durian peels and banana midribs become the second independent variable with categories 50:50, 60:40, and 70:30.

Figure 4 shows the effect of variations in the composition of raw materials and particle size on the value of the $\mathrm{CD}$. The mean $\mathrm{CD}$ values obtained in this investigation range from $1.1349-1.4161 \mathrm{~g} / \mathrm{cm}^{3}$. The highest CD value is obtained from the composite of durian peels and banana midrib with a ratio of 50:50\% and a particle size of $104 \mu \mathrm{m}$. The lowest value is 
obtained from the same composition but with a particle size of $250 \mu \mathrm{m}$. However, this lowest value is higher than the results of Nuriana, Anisa, and Martana (2013) is research whose briquettes have a density of $0.99 \mathrm{~g} / \mathrm{cm}^{3}$. The $C D$ value decreases as the percentage of durian peels increases. The particle size affects the CD value, the lower the particle size, the higher the CD value obtained (Nuriana, Anisa, and Martana, 2014). The results of the CD analysis data show the $\mathrm{P}-\mathrm{V}$ alue of the variable carbon particle size and the variation in the composition of 0.0069 and 0.3668 . This means that the particle size has a significant effect on the $\mathrm{CD}$ value, while the composition variation does not have a significant effect. The P-value for each variable is significant if it is less than the level of significance (0.05) (Lind, Marchal, and Wathen, 2008).

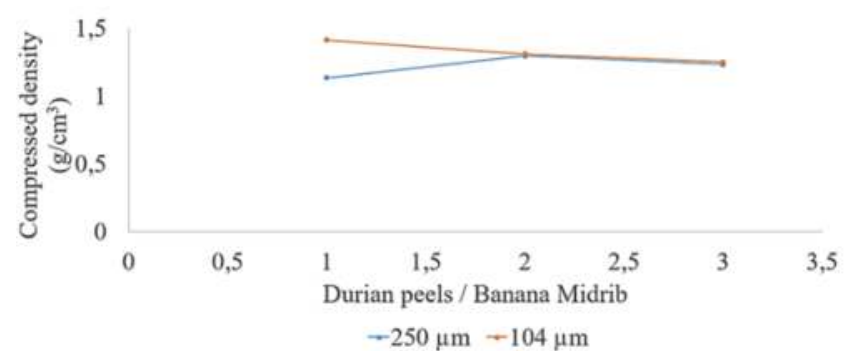

Fig. 4 Graph of compressed density to raw material composition ratio at 104 and $250 \mu \mathrm{m}$.

Figure 5 shows the increase and decrease in relaxed density (RD) due to the influence of the composition of the raw material and the carbon particle size. The average RD values vary between $0.7335-0.9724 \mathrm{~g} / \mathrm{cm}^{3}$. Briquettes with a composition of 50:50\% ratio of durian peels and banana midrib measuring $250 \mu \mathrm{m}$ have the highest $\mathrm{RD}$ value, while briquettes made from 70:30 \% with a size of $104 \mu \mathrm{m}$ have the lowest RD values. The graph illustrates that the higher the carbon particle size, the greater the RD value obtained. This value also decreases with an increasing percentage of durian peels. The P-Value of the carbon particle size variable and the variation in the composition are 9.2. $10^{-16}$ and 4.4. $10^{-13}$. This means that both variables have a significant effect on the RD value. This is also supported by the P-value of the interaction between the particle size and the small composition variation, which is $1.06 \cdot 10^{-11}$. Increases density value causes the calorific value contained in each $\mathrm{cm}^{3}$ of briquettes are higher so the quality will be better (Naim, Saputro, and Rusianto, 2013).

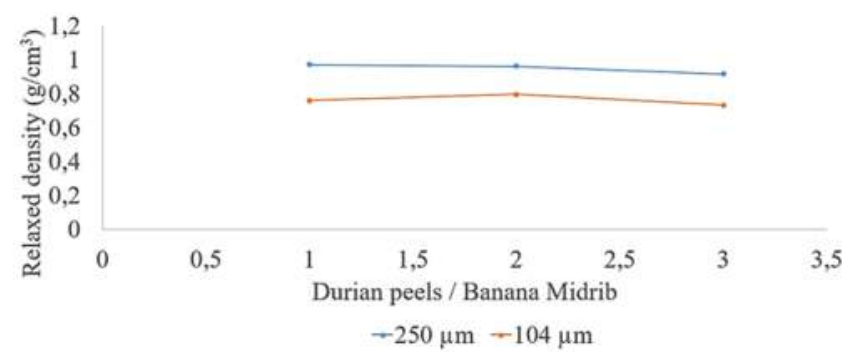

Fig. 5 Graph of relaxed density to raw material composition ratio at 104 and $250 \mu \mathrm{m}$.
Figure 6 shows the effect of variations in the composition of raw materials and particle size on the value of the Relaxation Ratio (RR). The mean RR values of this study ranged from 1.1832-1.8712. This value indicates that the briquettes obtained are relatively stable. The highest value is obtained from briquettes with a composition ratio of 50:50 raw materials and particle size of $104 \mu \mathrm{m}$, while the lowest value is obtained from the same composition but in $250 \mu \mathrm{m}$ particle size. The smaller particle size causes a higher relaxation ratio and briquette stability (Aransiola, Oyewusi, Osunbitan, and Ogunjimi, 2019). The results of the RR analysis data show the P-value of the variable carbon particle size and composition variations of $6.5 .10^{-10}$ and 0.000173 . This means that both of the variables are significant to the RR value. This is also supported by the P-value of the interaction between the particle size and the variation in composition which is quite small, which is 0.001271 . The ANOVA method makes it possible to expand the analysis to situations where the things being measured are influenced by two or more variables (Hanief, 2017).

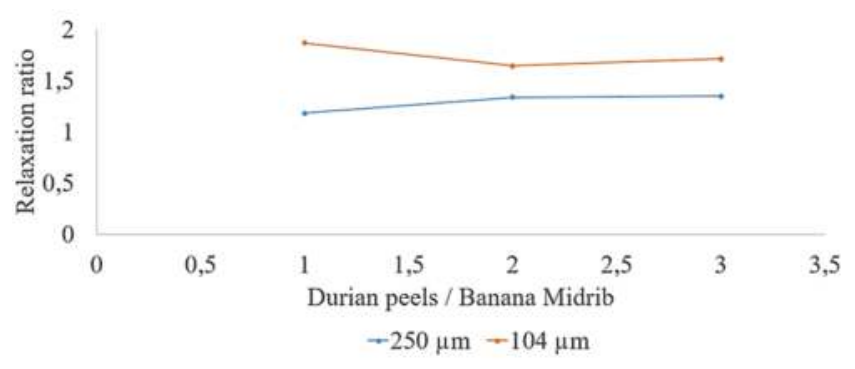

Fig. 6 Graph of relaxation ratio to raw material composition ratio at 104 and $250 \mu \mathrm{m}$.

Figure 7 shows the effect of the ratio of raw material composition and particle size on the percentage of moisture content (PMC) value. The PMC values obtained in this study ranged from $26.60-49.70 \%$. The results obtained are categorized as unfavorable when compared to the results of the study by Pallavi, Swikantaswamy, Kiran, Vyshnavi, and Ashwin (2013) who proposed a moisture content of 5-10\% for quality briquettes. The graph shows that briquettes with a size of $104 \mu \mathrm{m}$ have a higher PMC value than $250 \mu \mathrm{m}$. The highest and lowest PMC values are obtained from briquettes with a composition of 50:50\% 104 and $250 \mu \mathrm{m}$. The increases in durian peels' percentage cause PMC value decrease so the briquettes produced are better. The higher the PMC value, the higher the water content contained in the briquettes. This high-water content will make the briquette burning rate low and produce a lot of combustion smoke (Aransiola, Oyewusi, Osunbitan, and Ogunjimi, 2019). 


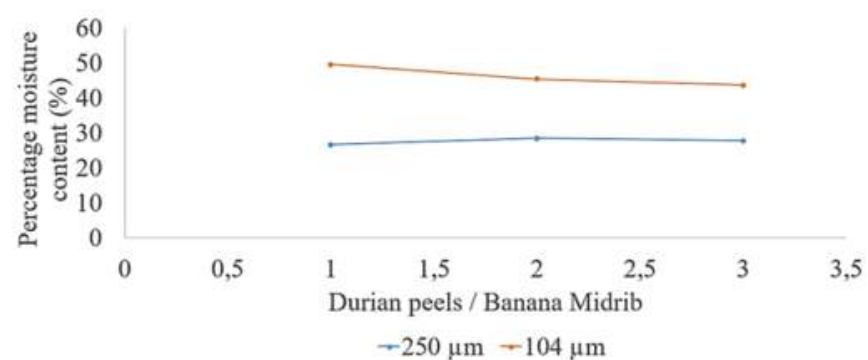

Fig. 7 Graph of moisture content percentage to raw material composition ratio at 104 and $250 \mu \mathrm{m}$.

Figure 8 shows the effect of the raw material composition and particle size on the value of the percentage water resistance index (PWRI). The PWRI value obtained from this study varies between 30.50-92.38\%. The highest PWRI value obtained from briquettes with a raw material composition ratio of $60: 40 \%$ in $104 \mu \mathrm{m}$ particle size, while the lowest value is obtained from the composition of $70: 30 \%$ in $250 \mu \mathrm{m}$ particle size. The PWRI value increases with decreasing carbon particle size. This occurs because briquettes with smaller particle sizes have less pore space which can reduce capillary action and percolation of water so these briquettes have a better ability to resist water penetration. The results of the PWRI analysis data shows the $\mathrm{P}$-value of the variable carbon particle size and composition variations of $6.4 \cdot 10^{-8}$ and 0.024377 . This means that both of the variables have a significant effect on the RR value. The briquettes with the highest PWRI value are of higher quality because they are not easily destroyed when absorbing water
(Ajimotokan, Ibitoye, Odusote, Adesoye, and Omoniyi, 2019).

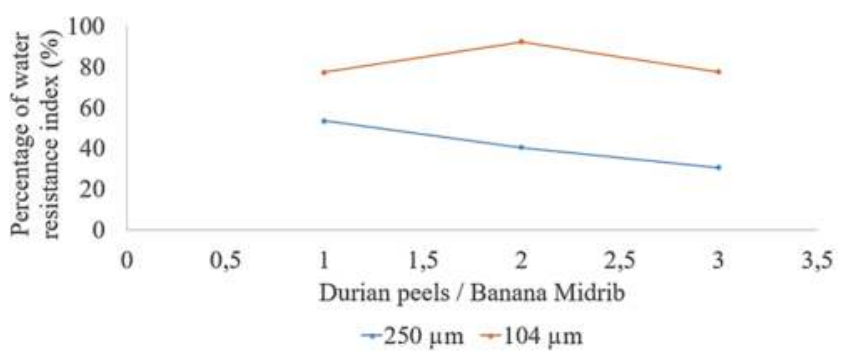

Fig. 8 Graph of the percentage of water resistance index to the ratio of raw material composition at 104 and $250 \mu \mathrm{m}$

Table 2 shows the results of the WBT as a function of raw material composition and carbon particle size. The water boiling test evaluates the thermal efficiency and the specific fuel consumption of briquettes (Sawadogo, Tanoh, Sidibe, Kpai, and Tankoano, 2018). The data obtained explains that the smaller size of the carbon particles has a longer time for briquettes used to boil water. Also, the smaller size of the carbon particles will cause the temperature of the water to be higher. At a particle size of $250 \mu \mathrm{m}$, boiling time and highest temperature increases with the increase in the percentage of durian peels. Meanwhile, at a particle size of $104 \mu \mathrm{m}$, boiling time and the highest temperature decreases along with the increase in the percentage of durian peels. The best briquettes from the WBT-test results are briquettes with a particle size of $104 \mu \mathrm{m}$ and the ratio of $50: 50 \%$.

Table 2. Results of the water boiling test.

\begin{tabular}{|c|c|c|c|c|c|c|c|}
\hline \multirow[t]{2}{*}{ Size $(\mu \mathrm{m})$} & \multirow[t]{2}{*}{ Durian peels: banana midrib } & \multicolumn{3}{|c|}{ Boiling duration (min) } & \multicolumn{3}{|c|}{ Highest temperature $\left({ }^{\circ} \mathrm{C}\right)$} \\
\hline & & 1 & 2 & 3 & 1 & 2 & 3 \\
\hline \multirow[t]{3}{*}{250} & $50: 50$ & 1.50 & 2.00 & 2.07 & 40.00 & 36.00 & 35.00 \\
\hline & $60: 40$ & 2.06 & 2.36 & 2.14 & 38.00 & 42.50 & 38.50 \\
\hline & $70: 30$ & 3.08 & 4.07 & 3.08 & 41.50 & 40.00 & 40.00 \\
\hline \multirow[t]{3}{*}{104} & $50: 50$ & 5.27 & 6.20 & 6.14 & 61.80 & 63.50 & 62.20 \\
\hline & $60: 40$ & 5.13 & 5.01 & 5.11 & 59.00 & 55.00 & 57.00 \\
\hline & $70: 30$ & 4.47 & 4.36 & 4.59 & 55.00 & 56.00 & 57.00 \\
\hline
\end{tabular}

Figure 9 shows the effect of the raw material compositions and particle sizes on the BR of briquettes. The BR value obtained in this study ranges from $0.5428-2.2388$ $\mathrm{g} / \mathrm{min}$. The graph shows that at a particle size of $104 \mu \mathrm{m}$, the BR value increases with a higher percentage of durian peels. However, at a particle size of $250 \mu \mathrm{m}$, the graph obtained is unstable (there is a drastic decrease in the composition of $60: 40 \%$ ratio of durian peels and banana midribs). This is possible because of the high moisture content in the briquettes has the highest PMC value when compared to other compositions at the size of $250 \mu \mathrm{m}$. Briquettes with a particle size of $250 \mu \mathrm{m}$ have a higher BR value than those with a size of $104 \mu \mathrm{m}$. The results of this analysis are in line with the conclusions of Chin and Siddiqui (2000) who stated that the BR increased with increasing particle size. This can be explained using porosity theory, where the finer the particle size, the lower the porosity, causing mass transfer (such as water vapor, volatile matter, and oxygen infiltration) to be inhibited. As a result, the rate of briquette weight reduction is low (Mohammed and Olugbade, 2015).
The two-way ANOVA test results from the BR characterization data show that the particle size and composition variations do not significantly affect the rate of combustion. This can be proven by the P-value BR for the variable particle size and composition variations of 0.222354 and 0.064121 . This insignificant value is determined from a $\mathrm{P}$-value that is greater than 0.05 (Irianto, 2004).

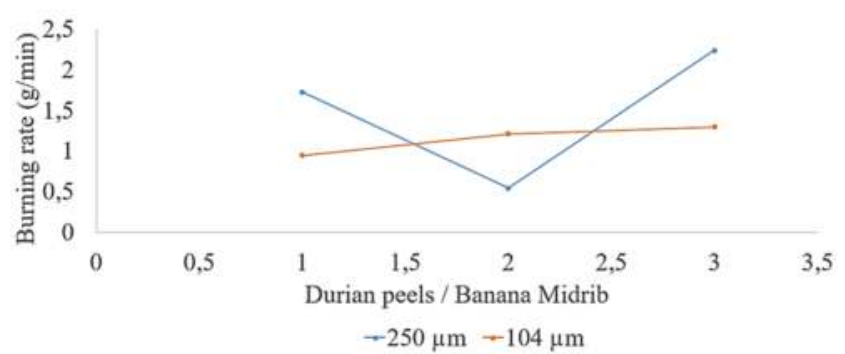

Fig. 9 Graph of burning rate to raw material composition ratio at 104 and $250 \mu \mathrm{m}$

Figure 10 shows the effect of variations in raw material composition and particle size on the value of SFC. SFC 
values in this study varies between $0.0118-0.0758 \mathrm{~g} / \mathrm{mL}$. The graph obtained does not show a linear relationship between SFC values and variations of composition and particle size. However, the SFC value of briquettes with a carbon particle size of $250 \mu \mathrm{m}$ is higher than $104 \mu \mathrm{m}$. The best briquettes obtained is when using the ratio of 60:40 and carbon particle size of $250 \mu \mathrm{m}$. This happens because the SFC value is used to measure the quantity of fuel needed to boil water. Thus, the smaller SFC value results in the better quality of the briquettes (Oyelaran, Bolaji, Waheed, and Adekunle, 2015). The ANOVA test results for the SFC analysis data show that the particle size and variable composition have a significant effect on the SFC value. This can be seen from the P-value which is less than 0.05 , namely 0,016427 and 0.005838 .

Figure 11 shows the effect of raw material compositions and carbon particle sizes on the percentage of durability index (PDI). PDI is a parameter that indicates the toughness of the produced briquette during storage, handling, and transportation (Ajimotokan, Ibitoye, Odusote, Adesoye, and Omoniyi, 2019). The results of the study show a good PDI score, where the average is between $77.45-97.24 \%$. The graph shows that the PDI value increases with the increase of particle size carbon and the percentage of durian peels in the briquette. The highest PDI value is obtained from the briquette with the composition of 70:30 ratio durian peels and banana midrib, measuring $250 \mu \mathrm{m}$, while the lowest value is obtained from the composition with a ratio of 60:40 measuring $104 \mu \mathrm{m}$. The PDI value obtained in this study is very high and safe if it is taken for a trip. Besides, $50 \%$ is an indicator of the lowest PDI value for acceptable resistance to shocks (S.R. Richards, 1990; Sawadogo, Tanoh, Sidibe, Kpai, and Tankoano, 2018). The ANOVA test results from the PDI data indicate that the particle size has a significant effect on the PDI value, while the variation in the composition does not significantly influence the PDI value. This can be shown from the P-value, where for the particle size the value is 0.028837 and for the variation in the composition of 0.092982 . Also, there is no interaction between the variable particle size and composition variations because the $\mathrm{P}$-value for the interaction is quite high. The interaction occurs when the combination of the two factors

\subsection{Qualitative Analysis of Student}

Figure 12 shows the percentage of IQ level of 30 students of Tasikmalaya, Indonesia who are the subjects in this study. Student demographic figures that include IQ points and the average score of mathematics, chemistry, physics, and biology from students were obtained before analyzing the pretest-posttest results. Students have a level of intelligence that varies from normal to very intelligent. The diagram shows that most students have a normal level of intelligence.

Figure 13 shows the percentage average score of science subjects (mathematics, chemistry, physics, and biology). The diagram illustrates the different levels of students' understanding of science subjects varying from 60-92.2. influences the variable being tested, in addition to each factor itself (Lind, Marchal, and Wathen, 2008).

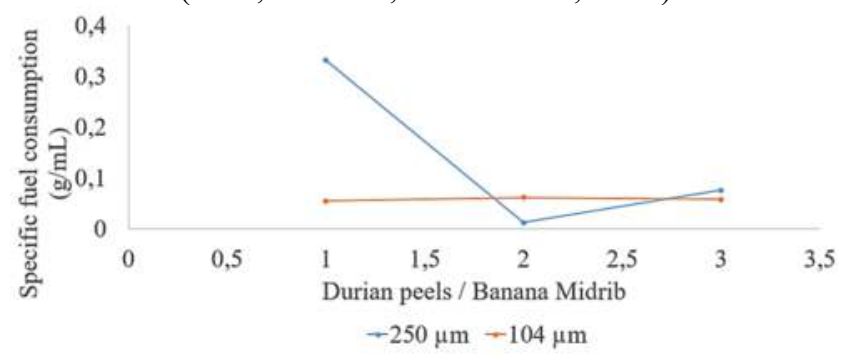

Fig. 10 Graph of the specific fuel consumption to the raw material

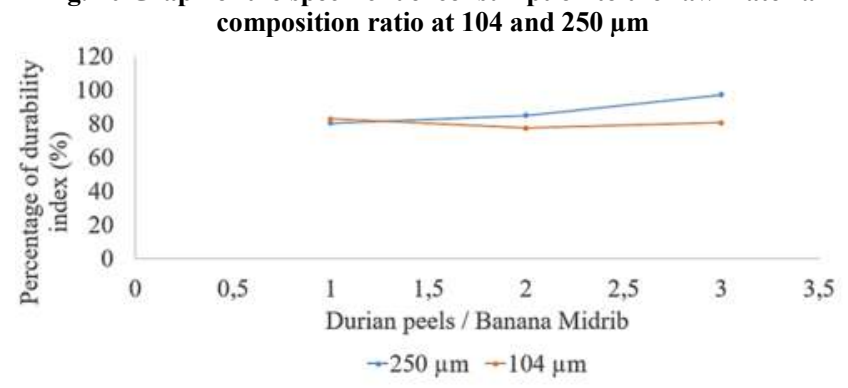

Fig. 11 Graph of the percentage of durability index to the ratio of raw material composition at 104 and $250 \mu \mathrm{m}$.

All test results show that the best density and WBT values are obtained from the ratio of 50:50 and 104- $\mu \mathrm{m}$ banana midribs. In addition, the PWRI value is quite high. However, the BR and PDI values are very low, so the briquettes produced are quite stable and last a long time when burning but the combustion rate is low and produces a lot of smoke and is brittle and easily damaged when it receives shocks even though it is resistant to water absorption. When the briquettes are compared with the briquettes with a ratio of 70:30 and $250 \mu \mathrm{m}$ banana midribs, it can be seen that the density and WBT values are close to the best values. Besides, the BR and PDI values are very high, so that the briquettes are quite stable with low moisture content (low PMC values). This also shows that the calorific value and combustion rate are high so the quantity of fuel is getting better and stronger against shocks. This statement is also supported by its low SFC value so the briquettes produced are quite economical (Oyelaran, Bolaji, Waheed, and Adekunle, 2015).

Table 3 shows the student grade scores for the whole question. This data shows the effect of providing learning material using the experimental demonstration methods regarding the briquettes given to students which has a positive impact which can be seen from the increase in value. This is in line with the results of research by Agus and Budi (2014) which state that the use of experimental demonstration methods can increase student activity and learning outcomes.

The pretest results show that not all students understand about briquettes, but most of them can answer the questions given. There is a unique thing that happened, where the value for question number $4^{*}$ does not increase at all. This can 
happen because students are still unable to analyze the material implied in the video. Overall, the pretest-posttest analysis shows an increase in students' understanding of briquettes. The results of the analysis also show that students' IQ points are not the only factor affecting student scores. This is in line with the results of research by Nandiyanto, Raziqi, Dallyono, and Sumardi (2020) which states that in addition to IQ points, appropriate learning methods can improve student understanding. Measuring the increase in student understanding after the instructional video is given conducted through a posttest.

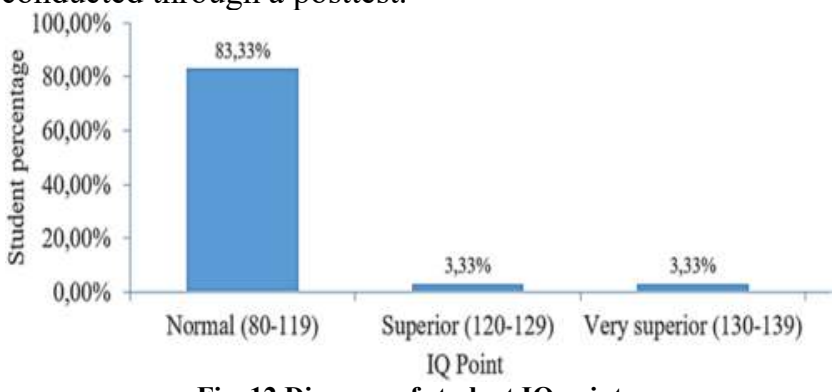

Fig. 12 Diagram of student IQ points.

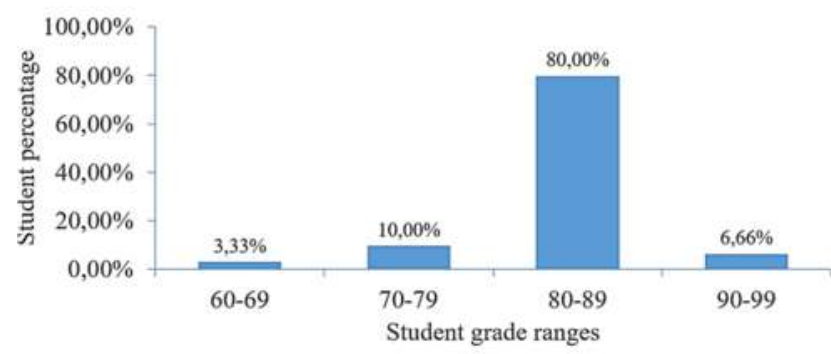

Fig. 13 Diagram of student mean score

To find out an increase in understanding of the concept of making briquettes from a mixture of durian peels and banana midribs after being given treatment, the pretest and posttest results obtained are tested using paired t-test. Before the paired t-test can be used, the normality test of the research data is carried out because the data has a small sample size, the normality test used is the Spahiro-Wilk test (Ain, 2013).

Table 4 shows the results of the pretest and posttest data normality test. The table shows that the significance value for the pretest and posttest scores is 0.003 . This value is smaller than 0.05 , so it can be concluded that the data are not normally distributed with $95 \%$ reliability. The decisionmaking criterion is normally distributed if the value of Sig $>$ 0.05 (Kurniadi and Purwaningrum, 2018).

Table 3. Comparison of Student Score (\%)

\begin{tabular}{|c|c|c|c|c|}
\hline \multirow[t]{2}{*}{ No. } & \multirow{2}{*}{ Question } & \multicolumn{3}{|c|}{ Skor (\%) } \\
\hline & & Pretest & Posttest & Gain \\
\hline 1. & $\begin{array}{l}\text { Bio briquettes are briquettes made from biomass, while bio-charcoal briquettes are briquettes made from } \\
\text { carbonization }\end{array}$ & 78.10 & 96.70 & 18.60 \\
\hline 2. & $\begin{array}{l}\text { The carbon raw material for briquettes is obtained from the carbonation process from agro-industrial waste. } \\
\text { Then, briquettes are made by mixing raw materials that have been carbonated with adhesive. Banana } \\
\text { midribs and durian peels can be used as raw materials for making briquettes. }\end{array}$ & 78.10 & 96.70 & 18.60 \\
\hline 3. & $\begin{array}{l}\text { The carbon raw material for briquettes is obtained from the carbonation process from agro-industrial waste. } \\
\text { Then, briquettes are made by mixing raw materials that have been carbonated with adhesive. Carbonation } \\
\text { is the process of converting organic material into charcoal. }\end{array}$ & 71.90 & 76.70 & 4.80 \\
\hline $4 .^{*}$ & $\begin{array}{l}\text { The carbon raw material for briquettes is obtained from the carbonation process from agro-industrial waste. } \\
\text { Then, briquettes are made by mixing raw materials that have been carbonated with adhesive. Briquettes } \\
\text { made from raw materials with high water content (such as banana stems) show a higher calorific value } \\
\text { than raw materials with low water content (such as durian peels) }\end{array}$ & 50.00 & 50.00 & 0.00 \\
\hline 5. & $\begin{array}{l}\text { The carbon raw material for briquettes is obtained from the carbonation process from agro-industrial waste. } \\
\text { Then, briquettes are made by mixing raw materials that have been carbonated with adhesive. Variations in } \\
\text { the composition of raw materials can affect the quality of the briquettes. }\end{array}$ & 75.00 & 90.00 & 15.00 \\
\hline 7. & $\begin{array}{l}\text { The carbon raw material for briquettes is obtained from the carbonation process from agro-industrial waste. } \\
\text { Then, briquettes are made by mixing raw materials that have been carbonated with adhesive. The briquette } \\
\text { is made from banana midribs and durian peels. If the number of durian peels is greater than banana stems, } \\
\text { the briquettes produced will be of higher quality than those made from banana midribs alone. }\end{array}$ & 75.00 & 83.30 & 8.30 \\
\hline 8. & $\begin{array}{l}\text { The carbon raw material for briquettes is obtained from the carbonation process from agro-industrial waste. } \\
\text { Then, briquettes are made by mixing raw materials that have been carbonated with adhesive. The } \\
\text { carbonization process in making briquettes must be carried out until the black raw material is perfect. }\end{array}$ & 81.30 & 90.00 & 8.70 \\
\hline 9. & $\begin{array}{l}\text { The carbon raw material for briquettes is obtained from the carbonation process from agro-industrial waste. } \\
\text { Then, briquettes are made by mixing raw materials that have been carbonated with adhesive. The size of } \\
\text { the carbon particles can affect the quality of the briquettes. }\end{array}$ & 84.40 & 96.70 & 12.30 \\
\hline 10. & $\begin{array}{l}\text { The carbon raw material for briquettes is obtained from the carbonation process from agro-industrial waste. } \\
\text { Then, briquettes are made by mixing raw materials that have been carbonated with adhesive. The addition } \\
\text { of adhesive reduces the calorific value of the briquettes. }\end{array}$ & 75.00 & 90.00 & 15.00 \\
\hline
\end{tabular}




\begin{tabular}{|c|c|c|c|c|}
\hline 11. & $\begin{array}{l}\text { The carbon raw material for briquettes is obtained from the carbonation process from agro-industrial waste. } \\
\text { Then, briquettes are made by mixing raw materials that have been carbonated with adhesive. The emphasis } \\
\text { on the briquettes when printed aims to increase the density }\end{array}$ & 75.00 & 83.30 & 8.30 \\
\hline 12. & $\begin{array}{l}\text { The carbon raw material for briquettes is obtained from the carbonation process from agro-industrial waste. } \\
\text { Then, briquettes are made by mixing raw materials that have been carbonated with adhesive. One of the } \\
\text { parameters in briquettes is the specific fuel consumption (SFC), where SFC is the amount of briquette } \\
\text { usage that is consumed to produce energy. The higher the SFC, the better the quality of the briquette (more } \\
\text { economical). }\end{array}$ & 46.90 & 50.00 & 3.10 \\
\hline
\end{tabular}

Table 4. Normality Test of Students' Score Pretest-Posttest Data

\begin{tabular}{|l|c|c|c|}
\hline & \multicolumn{3}{|c|}{ Shapiro-Wilk } \\
\cline { 2 - 4 } & Statistic & df & Sig. \\
\hline Student Pretest Score & 0.761 & 12 & 0.003 \\
\hline Student Posttest Score & 0.757 & 12 & 0.003 \\
\hline
\end{tabular}

The pretest and posttest results data that are not normally distributed indicates that the paired t-test could not be done. This happens because the requirement for the paired t-test is that the data must be normally distributed (Suryono and Rejekiningsih, 2007). Therefore, a non-parametric Wilcoxon signed-rank test is conducted to determine whether there is a difference in the mean of the two paired samples (pretestposttest scores) (Gehan, 1965).

Table 5 shows the Output Ranks on the Wilcoxon Signed Ranks Test from the students' pretest-posttest scores. The difference (negative) between the students' scores for the pretest-posttest is 0 , be it the $\mathrm{N}$ value, the Mean Rank, or the Sum Rank. This value of 0 indicates that there is no decrease from the pretest to posttest scores. The table shows that the difference (positive) between students' scores for the pretestposttest is $11(\mathrm{~N})$. This means, 11 questions (except *4) experienced an increase in score with an average value increase (Mean rank) of $6 \%$. Meanwhile, Ties shows the similarity of the pretest-posttest scores, here the Ties value is 1 so it can be said that there is the same value between the pretest and posttest scores of the students. This happened in question number 4 , where there is no increase in the value of the students. Overall, it can be concluded that the experimental demonstration method through learning videos of making briquettes from durian peels and banana stalks can improve students' understanding.

Table 5. Ranks Wilcoxon Signed Ranks Test of Students' Score Pretest-Posttest Data

\begin{tabular}{|l|l|c|c|c|}
\hline \multicolumn{2}{|l|}{} & N & $\begin{array}{c}\text { Mean } \\
\text { Rank }\end{array}$ & $\begin{array}{c}\text { Sum of } \\
\text { Ranks }\end{array}$ \\
\hline $\begin{array}{l}\text { Posttest Score - Pretest } \\
\text { Score }\end{array}$ & $\begin{array}{l}\text { Negative } \\
\text { Ranks }\end{array}$ & $0^{\mathrm{a}}$ & 0.00 & 0.00 \\
\cline { 2 - 5 } & $\begin{array}{l}\text { Positive } \\
\text { Ranks }\end{array}$ & $11^{\mathrm{b}}$ & 6,00 & 66.00 \\
\cline { 2 - 5 } & Ties & $1^{\mathrm{c}}$ & & \\
\cline { 2 - 5 } & Total & 12 & & \\
\hline a. Posttest Score < Pretest Score \\
\hline b. Posttest Score > Pretest Score \\
\hline c. Posttest Score = Pretest Score \\
\hline
\end{tabular}

Table 6 shows the results of the Wilcoxon signed-rank test analysis based on negative ranks from the pretestposttest data. In the table, it can be seen that the Asymp.sig value is smaller than 0.05 . So, it can be concluded that there is a difference between student scores for the pretest and posttest questions and there is an effect of using the experimental demonstration learning method using video on student learning outcomes (Efendi and Suswanto, 2014).

Table 6. Statistics Wilcoxon Signed Ranks Test of Students' Score

\begin{tabular}{|l|r|}
\hline & Pretest-Posttest Data \\
\hline $\mathbf{Z}$ & \multicolumn{1}{|c|}{ Posttest Score - Pretest Score } \\
\hline Asymp. Sig. (2-tailed) & -2.938 \\
\hline
\end{tabular}

Figure 14 shows the comparison of student scores before and after the experimental demonstration is carried out. The results of the graph analysis show that the students' scores for each question (except $4 *$ ) increases after being given the instructional video. This is in line with the results of a study conducted by Hidayati, Adi, and Praherdhiono (2019) which states that the use of video in learning can improve student understanding.

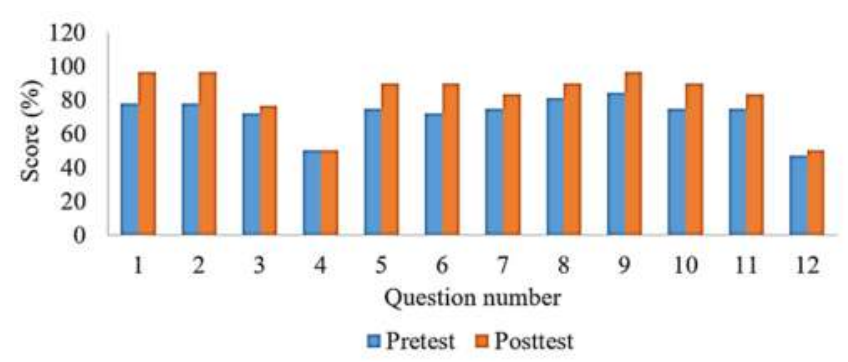

Fig. 14 Graph of students' scores against each question number.

\section{Conclusion}

The teaching of bio-charcoal briquettes production from a mixture of durian peels and banana midribs has been studied. Characterization through testing compressed density, relaxed density, relaxation ratio, percentage moisture content, percentage of water resistance index, water boiling test, burning rate, specific fuel consumption, and percentage of durability index show that the best briquette results obtained in this study are when using 70:30 ratio of durian peels and banana midrib with a carbon particle size of $250 \mu \mathrm{m}$. The results of the pretest-posttest show that most students experienced an increase in understanding of briquettes after being given learning through video. The whole analysis shows that a mixture of durian peels and banana midribs could be used as raw material for making briquettes. Learning media in the form of videos can also be used as an alternative in increasing student understanding, especially those that are not specifically taught in schools. This research has positive implications, where the results obtained can be used as a parameter in the consideration of those who wish to carry out further research. Further research is recommended to use independent variables such 
as the type of the adhesive or variations in the adhesive composition.

\section{Acknowledgements}

We acknowledged RISTEK BRIN (grant: Penelitian Terapan Unggulan Perguruan Tinggi) and Bangdos Universitas Pendidikan Indonesia.

\section{References}

A. Efendi and B. Siswanto. (2017) Penerapan Demonstration and Experiment Sebagai Upaya Meningkatkan Prestasi dan Keaktifan Belajar Siswa Mata Pelajaran Pekerjaan Dasar Konstruksi Bangunan Di Smk Negeri 2 Surakarta, Jurnal Ilmiah Pendidikan Teknik dan Kejuruan, 10(1), 16-24.

Ain, T. N. (2013) Pemanfaatan Visualisasi Video Percobaan Gravity Current Untuk Meningkatkan Pemahaman Konsep Fisika Pada Materi Tekanan Hidrostatis, Jurnal Inovasi Pendidikan Fisika, 2(2), 97-102.

Ajinomotokan, H. A., Ebitoye, S. E., Odusote, J.K., Adesoye, O. A., and Omoniyi, P. P. (2019) Physicomechanical Properties of Composite Briquettes from Corncob and Rice, Journal of Bioresources and Bioproducts, 4(3), 159-165.

Asmara, A. P. (2015) Pengembangan Media Pembelajaran Berbasis Audio Visual Tentang Pembuatan Koloid, Jurnal Ilmiah Didaktika, 15(2), 156-178.

Aransiola, E. F., Oyewusi, T.F., Osunbitan, J.A., and Ogunjimi, L. A. O. (2019) Effect of binder type, binder concentration and compacting pressure on some physical properties of carbonized corncob briquette, Energy Reports, 5, 909-918.

Chin, O. C. and Siddiqui, K. M. (2000) Characteristics of some biomass briquettes prepared under modest die pressures, Biomass and Bioenergy, 18, 223-228.

Christian, D. G. (2000) Biomass for Renewable Energy, Fuels, and Chemicals, Journal of Environmental Quality, 29(2), 662-663.

Elfiano, E., Subekti, P. and Sadil, A. (2014) Analisa Proksimat dan Nilai Kalor pada Briket Bioarang Limbah Ampas Tebu dan Arang Kayu, Jurnal Aptek, 6(1), 57-64.

Feng, J., Wang, Y., Yi, X., Yang, W., and He, X. (2016) Phenolics from Durian Exert Pronounced No Inhibitory and Antioxidant Activities, Journal of Agricultural and Food Chemistry, 64(21), 4273-4279.

Gehan, E. A. (1965) A Generalized Wilcoxon Test For Comparing Arbitrarily Singly-Censored Sample, Biometrika, 52(1-2), 203-224.

Gemco. (2020), Over View the Process of Charcoal Making, Anyang GEMCO Energy Machinery, Nanyang.
Hanif, Y. (2017), Statistik Pendidikan, CV Budi Utama, Sleman.

Hendra, D. (2011) Pemanfaatan Eceng Gondok (Eicbornia crassipes) untuk Bahan Baku Briket Sebagai Bahan Bakar Alternatif, Jurnal Penelitian Hasil Hutan, 29 (2), 189-210.

Hidayati, A., Adi, E. and Praherdhiono, H. (2019) Pengembangan Media Video Pembelajaran untuk Meningkatkan Pemahaman Materi Gaya Kelas IV si SDN Sukoiber 1 Jombang, Jurnal Inovasi dan Teknologi Pembelajaran Kajian dan Riset dalam Teknologi Pembelajaran, 6(1), 45-50.

Indah, S., and M, H. D. (2012). Pembuatan Briket Arang dari Campuran Buah Bintaro dan Tempurung Kelapa Menggunakan Perekat Amilum. Jurnal Teknik Kimia 18 (1), 24-31.

Irhamni, Saudah, Hakim, L., Diana, Suzanni, M. A., and Ernilasari. (2019) PKM Masyarakat dalam Memanfaatkan Bonggol Jagung dan Kulit Durian menjadi Briket di Kawasan Wisata Ulee Lhee, Jurnal Pengabdian pada Masyarakat, 1(2), 88-94.

Irianto, A. (2004). Statistik : Konsep Dasar, Aplikasi, dan Pengembangannya, PT Pajar Interpratama Mandiri, Jakarta.

Kurniadi, G., and Purwaningrum, J. P. (2018) Kemampuan Pemahaman Matematis Siswa Melalui Discovery Learning Berbantuan Asesment Hands on Activities, Jurnal Ilmiah Pendidikan Matematika, 1(1), 8-13.

Lind, D., Marchal, W., and Wathen, S. (2008) Statistical Technique in Business and Economics with Global Data Sets, Mc-GwarHill, New York.

Maryanti, R., Hufad, A., Sunardi, S., Nandiyanto, A. B. D., and Al-Obaidi, A.S.M. (2020). Understanding covid-19 particle contagion through aerosol droplets for students with special needs. Journal of Engineering Science and Technology, 15(3), 1909-1920.

Masthura. (2019) Analisis Fisis Dan Laju Pembakaran Briket Bioarang Dari Bahan Pelepah Pisang, Journal of Islamic Science and Technology, 5 (1), 58-66.

Mohammed, T. and Olugbade, T. (2015) Burning Rate of Briquettes Produced from Rice Bran and Palm Kernel Shells, International Journal of Material Science Innovations, 03(02), 68-73.

Naim, D., Saputro, D. D. and Rusiyanto. (2013) Pengaruh Variasi Temperatur Cetakan Terhadap Karakteristik Briket Kayu Sengon pada Tekanan Kompaksi 5000 PSIG, Journal of Mechanical Engineering Learning, 2(1).

Nandiyanto, A. B. D., Raziqi, G. Y., Dallyono, R., and 
Sumardi, K. (2020) Experimental Demonstration for Enhancing Vocational Students 'Comprehension on Heat Transfer through Conduction and Radiation of Light Bulb', journal of technical education and training, 3(12), 189-195.

Nuriana, W., Anisa, N. and Martana. (2013) Karakteristik Biobriket Kulit Durian Sebagai Bahan Bakar Alternatif Terbarukan, Jurnal Teknologi Industri Pertanian, 23(1), 7076.

Nuriana, W., Anisa, N. and Martana. (2014) Synthesis preliminary studies durian peels bio briquettes as an alternative fuel, Energy Procedia, 47, 295-302.

Nurul, A., and Diyah, S. Y. (2018). Pengaruh Pendidikan Kesehatan dengan Media Video dan Metode Demonstrasi Terhadap Pengetahuan SADARI. Jurnal Care 6 (2), 162-174.

Oyelaran, O. A., Bolaji, B. O., Waheed, M. A., and Adekunle, M. F. (2015) Performance Evaluation of the Effect of Waste Paper on Groundnut Shell Briquette, International Journal of Renewable Energy Development, 4(2), 95-101.

Pallavi, H., Swikantaswamy, Kiran, Vyshnavi, and Ashwin. (2013) Briquetting agricultural waste as an energy source, J. Environ. Sci. Comput. Sci. Eng. Technol, 2(1), 160-172.

Rahman, S. (2018), Teknologi Pengolahan Tepung dan Pati Biji-Bijian, CV Budi Utama, Yogyakarta.
Richards, S.R., (1990) Physical testing of fuel briquettes. Fuel Process. Technol. 25, 89.

Rohendi Dedi, D. (2017) Efektivitas Metode Pembelajaran Demonstrasi Terhadap Peningkatan Hasil Belajar Siswa Kelas X Pada Mata Pelajaran Keterampilan Komputer dan Pengolahan Informasi di Sekolah Menengah Kejuruan. Jurnal Pendidikan Informasi dan Komunikasi 3 (1), 16-18.

Richards, S. R. (1990) Physical Testing of Fuel Briquettes, Fuel Process. Technol, 25, 89-100.

Sawadogo, M., Tanoh, S. T., Sidibe, S., Kpai, N., and Tankoano, I. (2018) Cleaner production in Burkina Faso: Case study of fuel briquettes made from cashew industry waste, 195, 1047-1056.

Sudradjat, R., Setiawan, D. and Roliadi, H. (2006) Teknik pembuatan dan sifat briket arang dari tempurung dan kayu tanaman jarak pagar (Jatropha curcas L.), Journal of Forest Product Research, 24(3), 1-16.

Yaumal, A., dan M, I. (2018) Pemanfaatan Limbah Cangkang Kelapa Sawit Menjadi Briket Arang Sebagai Bahan Bakar Alternatif, Journal of Civil Engineering and Vocational Education, 5(4), 1-8.

Zulkarnair. (2017), Budidaya Buah-Buahan Tropis, deepublish, Yogyakarta. 